\title{
Steatocystoma simplex of the lacrimal caruncle: a case report
}

\author{
Yuichiro Ishida', Yasuhiro Takahashi ${ }^{1}$ Emiko Takahashi ${ }^{2}$, Yoshiyuki Kitaguchi ${ }^{1}$ and Hirohiko Kakizaki ${ }^{*}$
}

\begin{abstract}
Background: This is the third reported case of a steatocystoma simplex in the lacrimal caruncle.

Case presentation: A 60-year-old male presented with a history of a slowly progressing mass in the right lacrimal caruncle since several years before his initial visit. At the first examination, a yellowish, relatively smooth surface mass was observed in the right lacrimal caruncle. The caruncular mass was completely removed under local anesthesia. The pathological findings of this mass were consistent with a steatocystoma. At the 6-month follow-up, there was no sign of recurrence or development of the steatocystoma or any other masses.

Conclusion: Although steatocystoma simplex rarely occurs in the lacrimal caruncle, it needs to be considered as a possible diagnosis for patients with a mass lesion in the caruncle.
\end{abstract}

Keywords: Steatocystoma, Lacrimal caruncle, Pathological findings

\section{Background}

Steatocystoma is a benign tumor thought to be a circumscribed malformation arising from the pilosebaceous duct junction [1]. Steatocystoma simplex is a noninheritable solitary counterpart of a steatocystoma multiplex [1-6]. Steatocystoma simplex commonly occurs in the skin of the forehead, nose, scalp, neck, axillae, chest, upper limbs, back, or legs [2-6]. In contrast, steatocystoma simplex in the periocular region is extremely rare $[4,5]$, with only two reported cases of a lacrimal caruncular lesion [2, 3].

In this case report, we present a case of a steatocystoma simplex in the lacrimal caruncle.

\section{Case presentation}

This study was approved by the ethics committee of Aichi Medical University Hospital (No. 2015-H011) and adhered to the tenets of the 1964 Declaration of Helsinki. Written informed consent was obtained from the patient for publication of this case report and any accompanying images.

A 60-year-old male presented with a history of a slowly progressing mass in the right lacrimal caruncle

\footnotetext{
* Correspondence: cosme@d1.dion.ne.jp

1Department of Oculoplastic, Orbital \& Lacrimal Surgery, Orbital \& Lacrimal Surgery, Aichi Medical University Hospital, 1-1 Yazako-Karimata, Nagakute, Aichi 480-1195, Japan

Full list of author information is available at the end of the article
}

since several years before his initial visit. There was no family history of any similar masses. The patient had no history of removal of any similar masses.

At the first examination, a yellowish, relatively smooth surface mass was observed in the right lacrimal caruncle (Fig. 1a). The patient also presented with similar masses in the right upper and left lower eyelid margins (Fig. 1a). Systemic examination did not detect any other skin lesions.

All three lesions were completely removed under local anesthesia without rupture. The cysts were not opened prior to histological processing. The pathological examination of the caruncular mass revealed a cyst lined by squamous epithelium (Fig. 1b). The cyst wall was thin and contained sebaceous glands (Fig. $1 \mathrm{~b}$ and c) $[5,6]$. Invaginations resembling hair follicles extended from the cyst wall into the surrounding stroma [7]. The epithelial layer was partially undulated (Fig. 1c) [5, 6]. Hairs were not found in the cyst lumen [5]. The findings were consistent with a steatocystoma. The pathological diagnoses of the other masses in the right upper and left lower eyelid margins were a hybrid epidermoid and apocrine cyst, and a hidrocystoma, respectively. At the 6-month follow-up, there was no sign of recurrence or development of the steatocystoma or any other masses. 

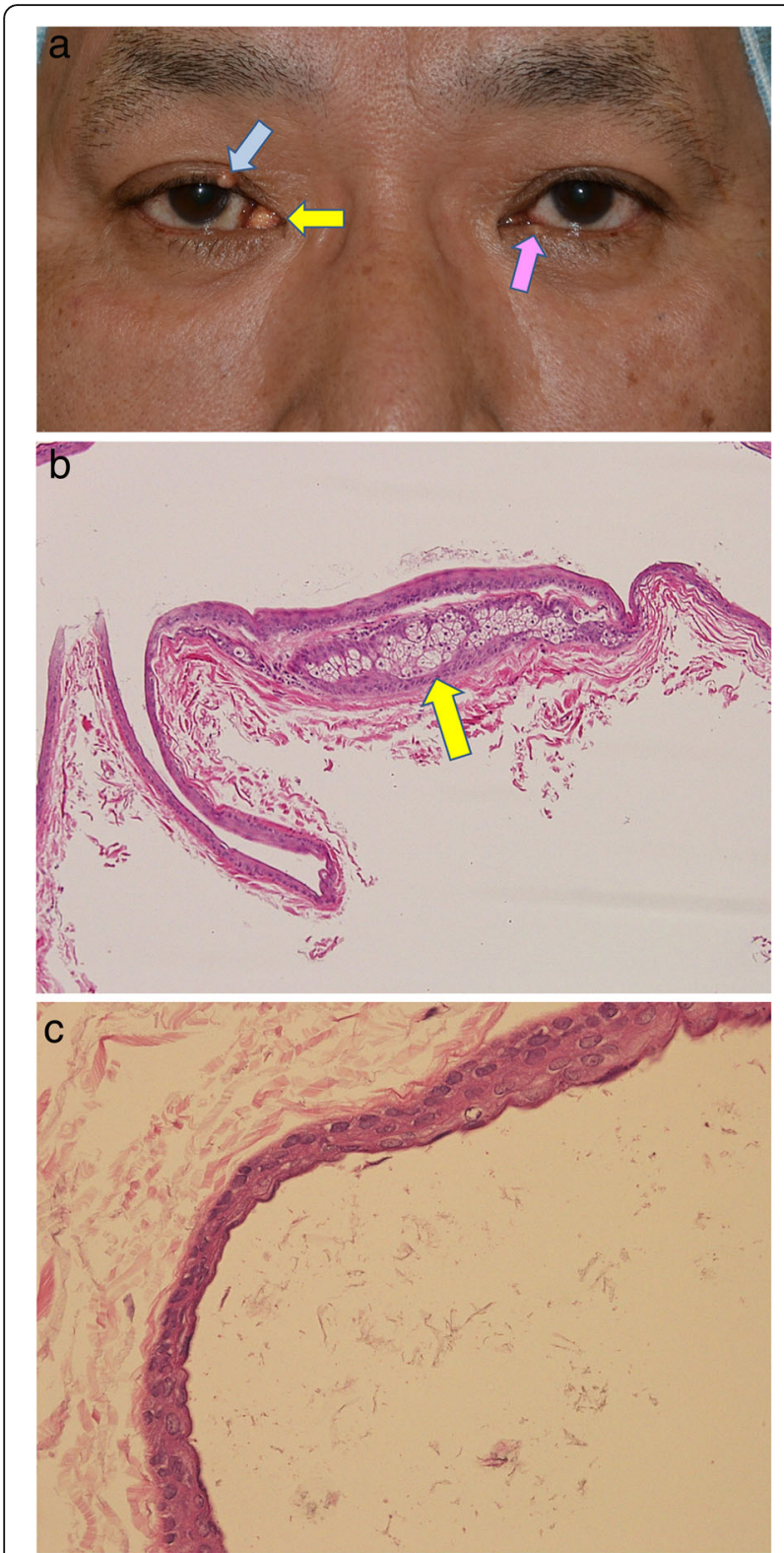

Fig. 1 a. A photograph of the patient's face. A yellow mass in the right caruncle (yellow arrow) and pale yellow nodules in the right upper (blue arrow) and left lower eyelid margins (pink arrow) are shown. b \& c. Pathological findings. b. A cystic mass is lined with stratified squamous epithelium and the cyst wall contains the sebaceous gland (arrow) (hematoxylin \& eosin stain; magnification $x$ 100). c. The cyst wall is three to four cells thick and is undulated without a granular cell layer (hematoxylin \& eosin stain; magnification $\times 400$ )

\section{Discussion}

We describe a case of a steatocystoma simplex in the lacrimal caruncle. Although 962 cases of lacrimal caruncular tumors have been previously reviewed in eight reports, none of them included steatocystomas [8-15]. Only two single case reports of a steatocystoma simplex in the lacrimal caruncle have been reported $[2,3]$.
The steatocystoma simplex is a cutaneous tumor thought to be a circumscribed malformation arising from the pilosebaceous duct junction [1]. As the lacrimal caruncle contains elements of both conjunctiva and skin [15], steatocystomas may have developed from the lacrimal caruncle, in a similar manner as other skin regions.

Differential diagnoses of the steatocystoma simplex in the lacrimal caruncle vary. An oncocytoma is a slowly progressing, cystic mass; however, it usually exhibits a reddish-blue tan color [10]. Although sebaceous gland hyperplasia, sebaceous gland adenoma, and lipogranuloma appear as yellow nodules, they present with different pathological findings [10]. Dermoid cysts show similar clinical and pathological findings to steatocystomas, although the dermoid cysts do not show an undulation in the epithelial layer without containing hairs in the lumen [5]. Cutaneous keratocysts also have a histopathological resemblance to steatocystoma by a festooned lining continuous with a thick stratified squamous wall that lacks a granular layer; however, sebaceous glands and lobules are typically lacking in the cutaneous cysts $[5,6]$.

\section{Conclusion}

In conclusion, we present a rare case of a steatocystoma simplex in the lacrimal caruncle. Steatocystoma simplex therefore needs to be considered as a possible diagnosis for patients with a mass lesion in the caruncle.

\section{Funding \\ None.}

\section{Availability of data and materials}

The authors confirm that all data underlying the findings are fully available without restriction. All relevant data are within the paper. A copy of the written consent is available for review by the Editor of this journal.

\section{Authors' contributions}

All authors qualified for authorship based on contributions to the conception and design (YT and HK), acquisition of the data (YT and ET), and analysis and interpretation of the data (YI, YT, ET, YK, and HK). All authors contributed to writing the manuscript, revising it critically for important intellectual content, and gave final approval of the version to be submitted for publication.

\section{Competing interests}

The authors declare they have no competing interests to declare.

\section{Consent for publication}

Written informed consent was obtained from the patient for publication of this case report and any accompanying images.

\section{Ethics approval and consent to participate}

This study was approved by the ethics committee of Aichi Medical University Hospital (No. 2015-H011) and adhered to the tenets of the 1964 Declaration of Helsinki.

\section{Author details}

'Department of Oculoplastic, Orbital \& Lacrimal Surgery, Orbital \& Lacrimal Surgery, Aichi Medical University Hospital, 1-1 Yazako-Karimata, Nagakute, Aichi 480-1195, Japan. ${ }^{2}$ Department of Pathology, Aichi Medical University Hospital, 1-1 Yazako-Karimata, Nagakute, Aichi 480-1195, Japan. 
Received: 6 November 2015 Accepted: 11 October 2016

Published online: 19 October 2016

\section{References}

1. Procianoy F, Golbert MB, Golbspan L, Duro KM, Bocaccio FJL. Steatocystoma simplex of the eyelid. Ophthal Plast Reconstr Surg. 2009;25:147-8.

2. Bowyer J, Sullivan T. Steatocystoma of the caruncle. $\mathrm{Br} J$ Ophthalmol. 2003:87:240-1.

3. Kim NJ, Moon KC, Khwarg SI. Steatocystoma of the caruncle. Can J Ophthalmol. 2006;41:83-5.

4. Tirakunwichcha S, Vaivanijkul J. Steatocystoma simplex of the eyelid. Ophthal Plast Reconstr Surg. 2009;25:49-50.

5. Kazakov DV, Michal M, Kacerovska D, McKee PH. Steatocystoma. In: Kazakov DV Michal M, Kacerovska D, McKee PH, editors. Cutaneous Adnexal Tumors. Philadelphia; Wolters Kluwer Health/Lippincott Williams \& Wilkins. 2012;368-72.

6. Jenkins JR, Morgan MB. Dermal cysts: a dermatopathological perspective and histological reappraisal. J Cutan Pathol. 2007:34:815-29.

7. Kirkham N. Tumors and cysts of the epidermis. In: Elder DE, Elenitsas R, Johnson BL Jr., Murphy GF, Xu X, editors. Lever's Histopathology of the Skin. Philadelphia; Wolters Kluwer Health/Lippincott Williams \& Wilkins. 2009;791-849.

8. Evans WH. Tumors of the lacrimal caruncle. A study of 200 collected cases. Arch Ophthalmol. 1940;24:83-106.

9. Luthra CL, Doxanas MT, Green WR. Lesions of the caruncle: A clinicopathologic study. Surv Ophthalmol. 1978;23:183-95.

10. Shields CL, Shields JA, White D, Augsburger JJ. Types and frequency of lesions of the caruncle. Am J Ophthalmol. 1986;102:771-8.

11. Wilson RP. Tumours and cysts of the lacrimal caruncle. Trans Ophthalmol Soc NZ. 1959:11:23-32.

12. Santos A, Gómez-Leal A. Lesions of the lacrimal caruncle: Clinicopathological features. Ophthalmology. 1994;101:943-9.

13. Serra GM. Tumori della caruncola lacrimale: Studio clinic ed anatomo patologico-casistica. Boll Ocul. 1928;7:783-802.

14. Kaeser PF, Uffer S, Zografos L, Hamédani M. Tumors of the caruncle: a clinicopathologic correlation. Am J Ophthalmol. 2006;142:448-55.

15. Levy J, Ilsar M, Deckel Y, Maly A, Pe'er J. Lesions of the caruncle: a description of 42 cases and a review of the literature. Eye. 2009;23:1004-18.

\section{Submit your next manuscript to BioMed Central and we will help you at every step:}

- We accept pre-submission inquiries

- Our selector tool helps you to find the most relevant journal

- We provide round the clock customer support

- Convenient online submission

- Thorough peer review

- Inclusion in PubMed and all major indexing services

- Maximum visibility for your research

Submit your manuscript at www.biomedcentral.com/submit 